\title{
Exercício do direito social de greve dos servidores públicos estatutários e políticas públicas*
}

\section{Exercise of the social right to strike of public servants and public policy}

Rodrigo Coimbra ${ }^{1}$

\section{Resumo}

A concretização da política pública que envolve o exercício direito social de greve dos servidores públicos passou por uma longa evolução no Brasil até o julgamento do Mandado de Injunção ${ }^{\circ} 712$ pelo Supremo Tribunal Federal, em 21/10/2007. No presente artigo pretende-se, após um breve escorço introdutório da greve, analisar esse julgamento histórico em que o Supremo Tribunal Federal, adotando a teoria concretista, efetivou o exercício desse importante direito social por meio da determinação de aplicação da Lei n. 7.783/89 aos servidores públicos, até que sobrevenha regulamentação do poder competente, concretizando importante política pública de desenvolvimento social e humano. Entende-se que o exercício desse direito precisa avançar no que tange à competência para o julgamento dos conflitos coletivos de trabalho (dentre os quais está a greve). Ainda que o artigo $8^{\circ}$ da Lei n. 7.783/89 defina ser da Justiça do Trabalho tal competência, o Supremo Tribunal Federal segue entendendo que a competência é da Justiça Estadual ou Federal e seus respectivos Tribunais, conforme a extensão territorial da greve (Mandado de Injunção 708, mantido esse posicionamento na Reclamação 6568). Conclui-se que esse posicionamento do Supremo Tribunal Federal merece ser revisto, mediante a interpretação tópico-sistemática da problemática, tendo como ponto de partida que a relação jurídica que se estabelece entre o servidor público e o Estado-Empregador, ainda que haja um estatuto de classe, é essencialmente trabalhista.

Palavras-chave: Servidor Público. Direito de Greve. Regulamentação. Supremo Tribunal Federal.

\footnotetext{
Abstract

The implementation of public policy that involves the exercise social right to strike of civil servants has gone through a long evolution in Brazil until the trial of the Injunctive Writ No. 712 by the Supreme Court occurred on 21/10/2007. In this article intends, after a brief introductory foreshortening of the strike, to analyze this historic trial in which the Supreme Court, adopting the theory concretist, effected the performance of this important social right through the determination of application of Law No. 7.783/89 civil servants, until we reach the competent regulatory power, fulfilling important public policy of social and human development. It is understood that this right must move forward regarding the authority to resolve conflicts collective bargaining (among which is the strike). While Article 8 of Law No. 7.783/89 to be
} 
available from the Labour Court that jurisdiction, the Supreme Court follows the view that the jurisdiction is the Federal or State Courts and their respective courts, according to the territorial extension of the strike (708 Writ of Injunction, maintained this position in the Complaint 6568). As a scientific method of approach will be used the deductive method. It is concluded that this position of the Supreme Court deserves to be reviewed by the interpretation of systematic problem-topic, taking as a starting point that the legal relationship established between the public servant and the State Employer, although there is a status class is essentially labor.

Key words: Public Policy. Social Law. Strike. Public Servants. Competence

\section{Introdução}

Mesmo com todas as dificuldades do movimento sindical, a greve ainda é vista com um movimento importante para a conquista de melhores condições de trabalho, por um lado. Por outro lado, a greve também causa grande desconforto para trabalhadores, empregadores e consumidores, usuários de serviços públicos, etc.

Trata-se de um tema de grande relevância para as relações sociais, com conexões importantes entre o Direito do Trabalho e outros ramos do conhecimento, tais como a Economia do Trabalho, a Sociologia do Trabalho, o Direito Constitucional e o Direito Administrativo.

Países que apresentam melhor desenvolvimento de sua negociação coletiva têm melhor distribuição de renda e menor distância entre ricos e pobres. Portanto, os conflitos coletivos de trabalho (entre os quais a greve faz parte, seja como ferramenta de pressão, seja como objeto de uma ação de dissídio coletivo) e sua forma de resolução via negociação coletiva, apesar de eventuais percalços, apresentam excelentes frutos para o desenvolvimento de um país e para a melhoria da condição geral de sua população.

O termo greve possui origem francesa. Decorre do antigo nome da Praça dos Paços do Conselho (Hôtel de Ville) em Paris. O nome é originário da situação do local às margens do rio Sena (Seine), tendo grève um significado de praia de cascalho. Nesse local foi criado um cais pelo preboste (preposto) dos mercadores Le Peletier, em 1673, local em que se realizavam as principais festas populares e onde estava o cadafalso em que se executa- vam criminosos. Ali era o lugar em que os trabalhadores, após a Revolução Francesa, quando abandonavam coletivamente ao trabalho iam para lá. Estavam em greve. Em espanhol o termo é huelga (folga). Em inglês o termo é strike (golpe), conforme estudo das origens históricas da greve feita por Pistori ${ }^{2}$.

No plano do direito positivo brasileiro, a greve tem previsões iniciais no final do século XIX, pois o trabalho livre era minoritário e com características muito limitadas até meados do século XIX, em razão da escravidão. Diante disso, a primeira lei da República Brasileira sobre greve foi o Decreto n. 847 de 11/10/1890 que tratava a greve como um ilícito penal. O Decreto n. 1.162, de 12/12/1890, também de natureza penal, alterou em parte o art. 205, assim como o art. 206, transformando a greve pacífica em não ilegal ${ }^{3}$.

Passando por omissões constitucionais (1891 e 1934) a greve foi tratada como delito de segurança nacional pela Lei n. 38 de 04/04/1935, sendo juntamente com o lockout considerados como "recursos anti-sociais e nocivos ao trabalho e ao capital" pela Constituição de 1937 (art. 139). A CLT (Decreto 5.452/43) tratou da greve e do lockout basicamente como penalidades (arts. 722 a 725, sendo posteriormente revogados os art. 723 a 725 pela Lei n. 9842/99). A Constituição democrática de 1946 reconheceu a greve como um direito e remete seu exercício a regulamentação por lei infraconstitucional (art. 158).

Com o golpe militar de 31/03/1964, a greve virou um direito sindical, contudo, a lei 4.330 de 01 de junho de 1964 introduziu uma série de embaraços para o seu exercício. A Constituição de 1967 assegurou a greve como direito dos trabalhadores, todavia não permitiu "nos ser-

2 PISTORI, Gerson Lacerda. Direito de greve: origens históricas e sua repercussão no Brasil. Caderno de Doutrina e Jurisprudência da Ematra 15. v.1, n.2, p. 40, mar./abr. 2005; Saliente-se que a reação ao contexto das péssimas condições de trabalho ainda na revolução industrial é dada pelos trabalhadores agrupados em sindicatos (Direito Coletivo do Trabalho e não pelo do Direito Civil - protetor do direito individual, na época, como sustentam muitos autores). Desde então, com sentido revolucionário ou simplesmente reformista, não parou mais a reivindicação dos trabalhadores por melhores condições de vida, conforme COIMBRA, Rodrigo; ARAÚJO, Francisco Rossal de. Direito do Trabalho: evolução do modelo normativo e tendências atuais na Europa. Revista Ltr. São Paulo, ano 73, t. 2, n. 08, p. 955, ago. 2009.

3 PISTORI, Gerson Lacerda. Direito de greve: origens históricas e sua repercussão no Brasil. Caderno de Doutrina e Jurisprudência da Ematra 15. v. 1, n. 2, p. 42, mar./abr. 2005. 
viços públicos e atividades essenciais, definidas em lei" (parágrafo $7^{\circ}$ do art. 157), o que foi mantido pela Emenda n. 1 de 1969. A Lei de segurança nacional n. 6.620/78 aumentou as penas para os grevistas e penalizou "a incitação à desobediência coletiva de leis".

A Constituição de 1988 assegura, dentro dos direitos e garantias fundamentais, direitos sociais amplos (sendo o trabalho contemplado entre direitos sociais previstos no art. $6^{\circ}$ ) e um significativo rol não taxativo de direitos para os trabalhadores e urbanos e rurais previstos no art. $7^{\circ}$, além de definir alguns aspectos de liberdade sindical no art. $8^{\circ}$ (ainda que muito restritiva) e o direito de greve como direito social no art. $9^{\circ}$, posteriormente, regulamentado pela Lei n. 7.783/89, relativamente aos trabalhadores da iniciativa privada.

Já no artigo 37, inciso VII, ${ }^{4}$ com redação dada pela Emenda Constitucional no 19/1998, a Carta Magna assegura o direito de greve aos servidores públicos, todavia remete seu exercício para ser regulamentado aos "nos termos e nos limites definidos em lei específica", daí porque tal direito possuiu eficácia contida até a decisão histórica do Supremo Tribunal Federal no julgamento do Mandado de Injunção 712, em 21/10/2007. Nessa oportunidade, o Supremo Tribunal Federal aplicou a Lei n. 7.783/89 e estendeu os efeitos desta decisão a todo o serviço público, concretizando importante política pública de desenvolvimento social e humano.

A partir dessa decisão do Supremo Tribunal Federal, de outras que vieram na seqüência, e da mudança dos tempos no serviço público, o problema principal do presente trabalho é questionar por que a Justiça do Trabalho ainda não é o órgão do poder judiciário brasileiro competente para julgar conflitos coletivos de trabalho, como o dissídio coletivo de greve, de servidores públicos celetistas e estatutários?

Como método científico de abordagem do assunto será utilizado o método dedutivo, que é aquele cujo antecedente é constituído de princípios universais, plenamente inteligíveis, do qual se chega a um conseqüente menos universal, inferir e concluir ao final ${ }^{5}$.

4 BRASIL. CF, art. 37, VII - "o direito de greve será exercido nos termos e nos limites definidos em lei específica; (Redação dada pela Emenda Constitucional no 19, de 1998)"

5 FINCATO, Denise Pires. A pesquisa jurídica sem mistérios: do projeto de pesquisa à banca. Porto Alegre: Notadez, 2008. p. 38.
A abordagem da pesquisa se dará pelo modelo qualitativo na medida em que se buscará o entendimento do fenômeno em seu próprio contexto. Em função das peculiaridades da pesquisa qualitativa a mesma tende a ser menos estruturada, de modo a trabalhar com o que é importante para os indivíduos, sistemas sociais, políticos, jurídicos e econômicos, utilizando-se para tanto, da investigação profunda sobre o tema proposto na presente pesquisa. Desta forma a mesma parte de questões ou focos de interesse amplos, que vão se definindo à medida que o estudo se desenvolve ${ }^{6}$.

\section{A greve e o serviço público}

O serviço público é por natureza estatal. É a atividade que o Estado exerce para cumprir seus fins. Maria Sylvia Di Pietro ${ }^{7}$ esclarece que alguns autores adotam um conceito mais amplo, enquanto outros preferem um conceito restrito: "nas duas hipóteses, combinam-se, em geral, três elementos para a definição: o material (atividades de interesse coletivo), o subjetivo (presença do Estado) e o formal (procedimento de direito público)". Para Cretella Júnior serviço público "é toda a atividade que o Estado executa direta ou indiretamente para a satisfação do interesse público, mediante procedimento de direito público". ${ }^{8}$ Na conceituação de Hely Lopes Meirelles: "serviço público é todo aquele prestado pela Administração ou por seus delegados, sob normas e controles estatais, para satisfazer necessidades essenciais ou secundárias da coletividade ou simples conveniências do Estado".

O serviço prestado pelo Estado é executado pelos agentes públicos que mantém vínculo de trabalho com a Administração Pública direta e indireta, podendo ser subdivididos $\mathrm{em}^{10}$ : a) servidores públicos: servidores públicos estatutários, regidos no âmbito da União pela Lei n. 8.112/90; servidores públicos celetistas, regidos pelo

6 MEZZAROBA, Orides; MONTEIRO, Cláudia Servilha. Manual de Metodologia da Pesquisa no Direito. 3 ed. São Paulo: Saraiva, 2006, p. 110.

7 DI PIETRO, Maria Sylvia Zanella. Direito Administrativo. 21. ed. São Paulo: Atlas, 2008, p. 90.

8 CRETELLA JUNIOR, José. Curso de Direito Administrativo. Rio de Janeiro: Forense. 2006, p. 311.

9 MEIRELLES, Hely Lopes. Direito administrativo brasileiro. 35 ed. São Paulo: Malheiros Editores, 2009, p. 332.

${ }^{10}$ Conforme classificação de DI PIETRO, Maria Sylvia Zanella. Direito Administrativo. 21 ed. São Paulo: Atlas, 2008, p. 485-491. 
Decreto-Lei n. 5.452/43 - Consolidação das Leis do Trabalho; servidores públicos temporários, regidos pela Lei n. 8.745/93; b) agentes políticos: são os titulares de cargos estruturais à organização política do país; c) militares: até a EC/18/98 eles eram tratados como "servidores militares", criando-se com isso mais um categoria de agente político. São pessoas físicas que prestam serviços às Forças Armadas - Marinha, Exército e Aeronáutica (art. 142, caput e parágrafo $3^{\circ} \mathrm{da} \mathrm{CF}$ ); d) particulares em colaboração com o poder público: nesta categoria entram as pessoas físicas que prestam serviços ao Estado sem vínculo empregatício, com ou sem remuneração, mediante delegação do poder público (ex. leiloeiros); requisição, nomeação ou designação para o exercício de funções públicas relevantes (ex. jurados) gestores de negócios (ex. pessoa que espontaneamente assume determinada função pública em momento de emergência, como no caso de uma enchente).

No período anterior à Constituição Federal de 1988 havia uma distinção da noção de servidor público e empregado público. Distinguia-se entre funcionário e servidor, sendo mais ampla a extensão do último termo. As expressões servidor público ou servidor do Estado tinham larga aceitação. Servidor era gênero, de que seriam espécies os funcionários públicos, os funcionários autárquicos, os admitidos em serviços de caráter temporário e os contratados para funções especializadas, conforme Arion Sayão Romita ${ }^{11}$. Em visão mais abrangente, incluindo os militares, servidor público podia ser considerado aquele que se encontra a serviço remunerado de pessoas jurídicas de direito público, havendo quatro espécies: funcionários, militares, contratados públicos e admitidos temporariamente. Nas empresas públicas, sociedades de economia mista e fundações não havia servidores, mas sim empregados. ${ }^{12}$

Após o advento da Constituição Federal de 1988 ainda persiste, em alguns autores, a tendência em separar os conceitos de servidor público e funcionário público ou entre funcionário público e empregado público, mas para o objetivo do presente trabalho não razão de ser para suposta distinção entre as expressões, uma vez que ambas se referem a mesma figura jurídica em sentido amplo, sendo

\footnotetext{
${ }^{11}$ ROMITA, Arion Sayão. Direito do Trabalho: Temas em Aberto. São Paulo: LTR. 1998, p. 782.

12 Ibidem, p. 782.
}

que os autores do presente ensaio optam pela expressão servidor público, por entenderem ser a mais abrangente e a mais adequada tecnicamente. Nesse contexto, servidor público em sentido amplo, é o titular, ainda que em caráter transitório de cargo, emprego ou função pública. E em sentido estrito, é a pessoa física titularizada que, em caráter permanente, exerce cargo público criado por lei. ${ }^{13}$

O servidor público, além dos deveres inerentes à sua função em sua relação de trabalho subordinado com o Estado, é titular de uma série de direitos assim como os trabalhadores da iniciativa privada, dispostos no art. 37 da Constituição Federal de 1988 entre os quais: os direitos à sindicalização ("direito à livre associação sindical" - inciso VI) e a greve (inciso VII).

Todavia, o exercício ao direito de greve aos servidores públicos garantido pela Constituição, foi por ela própria subordinado a criação de lei que o regulamente. Sem a devida regulamentação, com o passar dos anos e ante ao número crescente de greves no setor público e das questões controvertidas advindas destas greves, o judiciário foi aos poucos adotando um sistema que buscava a analogia com os trabalhadores da iniciativa privada, mais especificamente a Lei n. 7.783/89.

A Constituição Federal de 1967, originária do regime militar, em seu artigo 157, parágrafo $7^{\circ}$ e a Emenda Constitucional $n^{\circ} 1$, de 1969 , em seu artigo 162, vedavam a greve aos servidores públicos, em razão, sobretudo, do princípio da continuidade, visando impedir que fossem interrompidas atividades necessárias a atendimento do interesse público. O princípio da continuidade é a garantia de que as atividades realizadas pela administração pública serão ininterruptas, para que o atendimento do interesse da coletividade não seja prejudicado. ${ }^{14}$

A atual Constituição Federal, em seu artigo 37, inciso VII, garante o exercício ao direito de greve aos servidores públicos, entretanto tal direito possui eficácia contida, isto é, está subordinada a criação de lei que venha a regulamentar o exercício a este direito. ${ }^{15}$

\footnotetext{
${ }^{13}$ CRETELLA JUNIOR, José. Curso de Direito Administrativo. 18 ed. Rio de Janeiro: Forense. 2006, p. 326.

${ }^{14}$ MEDAUAR, Odete. Direito Administrativo Moderno. 10. ed. São Paulo: Revista dos Tribunais, 2006, p. 131.

${ }^{15}$ COIMBRA, Rodrigo. Direito do Trabalho. Novo Hamburgo: Feevale, 2006, p. 213.
} 
Conforme José Afonso da Silva ${ }^{16}$ o direito de greve, em tal caso, existe por força de norma constitucional, não por força de lei. Não é a lei que vai criar o direito. A Constituição já o criou. Nesses casos de norma de eficácia contida, a lei referida na norma, quando promulgada, é apenas restritiva do direito reconhecido, não geradora desse direito. Isso significa que enquanto a lei não vem, o direito há de prevalecer em sua amplitude constitucional. Reforça essa tese o fato de a Constituição ter garantido aos servidores públicos amplo direito à livre associação sindical (artigo 37, VI) que implica, só por si, o direito à greve. Então, se a lei não vem, o direito existe, e, se existe, pode ser exercido.

Todavia, diversamente de José Afonso da Silva, alguns autores entendem que o exercício de direito de greve era vedado aos servidores públicos, em razão da não criação de uma lei regulamentadora do direito, com bem prevê a Constituição Federal, como por exemplo, José Cláudio Monteiro Brito Filho ${ }^{17}$, que pondera que "enquanto a lei não for criada, não pode, do ponto de vista jurídico, ser exercido o direito de greve".

Esse entendimento é baseado numa concepção jurídica de que os servidores públicos são diferentes dos trabalhadores da iniciativa privada, e, portanto, não deve constituir objeto do mesmo sistema de proteção e garantias assegurado aos trabalhadores privados já que as atividades e serviços prestados pelos servidores públicos afetam, de forma mais acentuada, os interesses da população em geral. As greves no setor público infligem danos e incômodos injustificáveis às pessoas, bem mais do que a própria administração pública, além do mais são detentores de uma série de vantagens que reforçam o seu poder de negociação, começando pela estabilidade e a quase certeza de que os vencimentos dos dias paredistas não serão descontados, direitos que os trabalhadores da iniciativa privada não têm. ${ }^{18}$

A jurisprudência pátria também se direcionou, por longo tempo, por esta posição de não ser auto-aplicável o inciso VII do artigo 37 e, com isso, o servidor público não poderia exercitar o direito a greve sem a edição

\footnotetext{
${ }^{16}$ SILVA, Jose Afonso da. Curso de Direito Constitucional Positivo. 32 ed. São Paulo: Malheiros Editores, 2009, p. 700.

${ }^{17}$ BRITO FILHO, Jose Cláudio Monteiro de. Direito Sindical. São Paulo: LTR. 2000, p 314.

${ }^{18}$ ROMITA, Arion Sayão. Direito do Trabalho: Temas em Aberto. São Paulo: LTR. 1998, p. 591.
}

de lei regulamentadora, como no caso do julgamento do Mandado de Injunção $n^{\circ} 20$, quando o Supremo Tribunal Federal manifestou-se no sentido de que o direito ao exercício de greve do servidor público, previsto no artigo 37, inciso VII, era norma de eficácia limitada, e, portanto, desprovida de auto aplicabilidade. ${ }^{19}$

Ainda que houvesse entendimento jurisprudencial consolidado pelo Supremo Tribunal Federal nos termos acima, várias greves no setor público foram deflagradas no correr dos anos após o julgamento do Mandado de Injunção $n^{\circ} 20$, muitas delas inclusive no próprio judiciário, sem que os administradores públicos tenham usufruído da jurisprudência existente, em detrimento dos servidores públicos paredistas.

Na verdade, o que acabou ocorrendo foi a adoção de um sistema que buscava a analogia com os trabalhadores da iniciativa privada e mais especificamente a Lei n. 7.783/89. Era reconhecido o direito de greve aos servidores públicos, mas conciliava-se este direito a continuidade das atividades administrativas num padrão razoavelmente mínimo, para que a população não sofresse as consequências da interrupção dos serviços públicos e estabelecendo-se regras para o exercício, como por exemplo, a obrigatoriedade de comunicação prévia e a manutenção de um percentual mínimo de servidores em serviço. ${ }^{20}$

Por anos assim que ocorreu na prática, até o julgamento do Mandado de Injunção no 712 , ajuizado pelo Sindicato dos Trabalhadores do Poder Judiciário do Estado do Pará, que visava dar efetividade à norma inscrita no artigo 37, inciso VII da Constituição Federal ante a decretação de ilegalidade da greve dos servidores do ju-

\footnotetext{
19 "O preceito constitucional que reconheceu o direito de greve ao servidor público civil constitui norma de eficácia meramente limitada, desprovida, em conseqüência, de auto-aplicabilidade, razão pela qual, para atuar plenamente, depende da edição da lei complementar exigida pelo próprio texto da Constituição. A mera outorga constitucional do direito de greve ao servidor público civil não basta - ante a ausência de auto-aplicabilidade da norma constante do art. 37, VII, da Constituição - para justificar o seu imediato exercício. O exercício do direito público subjetivo de greve outorgado aos servidores civis só se revelará possível depois da edição da lei complementar reclamada pela Carta Política”. BRASIL. Supremo Tribunal Federal. Mandado de Injunção no 20: Rel. Min. Celso de Mello, Publicado no DJ de 22/11/1996. Disponível em http://www.stf.jus.br/portal/constituicao/artigo. asp\#ctx1. Acesso em: 05 nov. 2011.

${ }^{20}$ MEDAUAR, Odete. Direito Administrativo Moderno. 10. ed. São Paulo: Revista dos Tribunais, 2006, p. 280.
} 
diciário pelo Tribunal de Justiça do Pará, que determinou inclusive, o corte do ponto dos dias paralisados.

\section{0 julgamento do mandado de injunção $n$. 712 pelo supremo tribunal federal e concre- tização de políticas públicas}

O Supremo Tribunal Federal diante da falta de norma reguladora específica e a omissão legislativa, ao julgar o Mandado de Injunção 712, em 21/10/2007, em voto de relatoria do Ministro Eros Grau, acompanhado pela maioria dos demais ministros, aplicou a Lei $\mathrm{n}$. 7.783/89 adaptando-a aos servidores públicos e estendendo os efeitos desta decisão a todo o serviço público. ${ }^{21}$

Tal decisão histórica, por conceder o exercício do direito de greve aos servidores públicos e pelo fato do Supremo Tribunal Federal adotar a chamada teoria concretista em relação aos efeitos do mando de injunção, não se limitando a declarar a existência da omissão legislativa remetendo ao legislativo (teoria não concretista), mas concretizando o exercício do direito de greve, por meio da aplicação da Lei n. 7.783/89 aos servidores públicos, até que sobrevenha regulamentação do poder competente, concretizando importante política pública de desenvolvimento social e humano ${ }^{22}$.

Nessa decisão, o Supremo Tribunal Federal regulamentou o disposto no artigo 37, VII da Constituição Federal, integrando-o aos artigos $1^{\circ}$ ao $9^{\circ}, 14,15$ e 17 da Lei n. 7.783/89, alterando-os para colocá-los de acordo com as particularidades da greve no serviço público. As principais alterações propostas pelo Mandado de Injunção 712 foram quanto à quantidade de servidores em greve, pois segundo o disposto no referido Mandado de Injunção a greve no serviço público só poderá ser parcial e não mais total como era até então, pois alterou-se a redação do artigo $3^{\circ}$, da Lei n. 7.783/89 que dizia que: "Frustrada a negociação ou verificada a impossibilidade de recursos via arbitral é facultada a cessação coletiva do trabalho", sendo modificada para: "Frustrada a negociação ou

${ }^{21}$ SILVA, Antônio Álvares da. Greve no Serviço Público Depois da Decisão do STF. São Paulo: LTR. 2008, p. 119.

${ }^{22}$ A decisão pioneira historicamente em relação a utilização da teoria concretista pelo Supremo Tribunal Federal, ocorreu no julgamento do Mandado de Injunção 107, DJ 21.09.1990, de relatoria no Ministro Moreira Alves, conforme MORAES, Alexandre de. Direito Constitucional. 24.ed. São Paulo: Atlas, 2009, p. 177. verificada a impossibilidade de recursos via arbitral, é facultada a cessação parcial do trabalho".

A questão da paralisação parcial foi assim explicada pelo Ministro Eros $\mathrm{Grau}^{23}$, verbis:

a norma supletiva, na amplitude que a ela deve ser conferida no âmbito do presente mandado de injunção, compreende conjunto integrado pelos artigos $1^{\circ}$ ao $9^{\circ}, 14^{\circ}, 15^{\circ}$ e $17^{\circ}$ da Lei $n$. $7.783 / 89$, com as seguintes alterações necessárias ao atendimento das peculiaridades da greve nos serviços públicos: apenas a paralisação parcial do trabalho é facultada; durante a greve serão necessariamente mantidas em atividade equipes de servidores com o propósito de assegurar a regular continuidade da prestação do serviço público é inadmissível, consubstanciando abuso ao direito de greve.

Em relação a questão do pagamento ou não dos dias parados o artigo $7^{\circ}$ da Lei n. 7.783/89 foi recepcionado quase em sua redação originária. Artigo 7º:

Observadas as condições previstas nesta Lei, a participação em greve suspende o contrato de trabalho, devendo as relações obrigacionais, durante o período ser regidas pelo acordo, convenção, laudo arbitral ou decisão da Justiça do Trabalho.

O que foi modificado foi apenas o seu parágrafo único sendo que sua redação original era: "É vedada a rescisão de contrato de trabalho durante a greve, bem como a contratação de trabalhadores substitutos, exceto na ocorrência das hipóteses previstas no artigo 14". E ficou: “É Vedada a rescisão de contrato de trabalho durante a greve, exceto na ocorrência da hipótese prevista no artigo 14".

Nessa linha, sendo mantida a redação original do artigo $7^{\circ}$ da Lei n. 7.783/89, a partir da deflagração de uma greve de servidores públicos haverá a imediata sustação do pagamento dos salários dos grevistas. Os que trabalharem parcialmente para garantir a prestação parcial do serviço receberão proporcionalmente ao tempo de trabalho. Na prática, o servidor público não fará mais greve recebendo salário, não terá mais o privilégio de fazer greve sem ônus e sem risco, mas será o acordo, convenção, ou decisão da justiça que decidirá sobre o pagamento dos dias parados ou não. ${ }^{24}$

\footnotetext{
${ }^{23}$ BRASIL. Supremo Tribunal Federal. Mandado de Injunção $n^{\circ} 712$ : Rel. Min. Eros Grau, Publicado no DJ de 25/10/2007. Disponível em http://www.stf.jus.br/portal/constituicao/artigo.asp\#ctx1. Acesso em 05 nov. 2011.

${ }^{24}$ SILVA, Antônio Álvares da. Greve no Serviço Público Depois da Decisão do STF. São Paulo: LTR. 2008, p. 142.
} 
A jurisprudência do Superior Tribunal de Justiça caminhou na direção do imediato corte do ponto de grevistas, ignorando qualquer hipótese de negociação ou julgamento definitivo de dissídio. Em fevereiro de 2010, foi negada a liminar aos servidores do Ministério Público da União autorizando descontos financeiros em razão de greve realizada no final de 2009. Esta decisão era baseada no entendimento de que até então, os vários julgados do Superior Tribunal de Justiça sobre o tema, davam conta que seria possível o desconto dos dias parados por ocasião do movimento grevista, porém os descontos estavam limitados a $10 \%$ do salário integral do servidor grevista.

O entendimento foi de que os salários dos dias de paralisação só deveriam ser pagos no caso da greve ser injustamente provocada, seja pelo atraso no pagamento de salários, seja por outras situações excepcionais não provocadas pelos servidores que justificassem a greve.

Todavia, do início de 2010 até maio do mesmo ano, houve uma modificação radical no entendimento do Superior Tribunal de Justiça quanto ao corte do ponto dos servidores em greve: no julgamento da Medida Cautelar no 16774 a Primeira Seção da referida corte de justiça determinou que a União se abstivesse de realizar corte de vencimentos dos servidores grevistas do Ministério do Trabalho e Emprego. De acordo com a decisão relatada pelo Ministro Hamilton Carvalhido, "o vencimento é verba alimentar e cortá-lo significaria suprimir o sustento do servidor e da sua família”.

E o Superior Tribunal de Justiça passou a admitir o deferimento de medida cautelar preparatória, em se evidenciando a satisfação cumulativa dos requisitos de perigo de lesão grave e de difícil reparação ao direito da parte e de relevância da alegação, que devem ser afirmados, na espécie - enquanto não decidida eventual natureza legítima ou abusiva do movimento paredista no bojo da ação principal - à luz da natureza alimentar dos vencimentos, cuja supressão prévia poderá implicar em lesão grave e de difícil reparação, e à luz da letra da Lei n. 8.112/90, que não prevê hipótese de suspensão do vínculo administrativo-estatutário, tampouco de perda ou desconto de remuneração em decorrência de paralisação por motivo de greve, que não constitui falta injustificada ao serviço ${ }^{25}$.

Para os Ministros do Superior Tribunal de Justiça, diferentemente do que pensavam no início do ano de 2010, o corte nos vencimentos não é obrigatório, por entenderem que não existe previsão legal para a formação do fundo de custeio do movimento, bem como do imposto a ser pago pelo servidor para lhe assegurar o direito a greve. Além disso, consideraram os vencimentos dos servidores como verba alimentar, e que o corte do ponto traria grandes prejuízos aos servidores grevistas e que estes prejuízos seriam de difícil reparação.

Tal entendimento já pode ser vislumbrado nos demais tribunais do país, como por exemplo, na decisão liminar favorável aos servidores grevistas da Justiça Federal do Rio Grande do Sul dada pela Desembargadora Federal Silvia Maria Gonçalves Goraieb da $4^{\text {a }}$ Turma do Tribunal Regional Federal da $4^{\text {a }}$ Região contra o ato do Diretor do Foro da Seção Judiciária do Rio Grande do Sul que determinou o corte do ponto dos servidores em greve, nos autos do Mandado de Segurança 0018196-20.2010.404.0000:

assim, a fumaça do bom direito resta perfeitamente caracterizada. Não menos o perigo na demora resta configurado, considerando o fato de que os vencimentos são de natureza alimentar e os prejuízos tornar-se-iam irreversíveis diante da concretização de eventual desconto indevido. Portanto, com fundamento no art. $7^{\circ}$, III, da Lei $n^{\circ} 12.016 / 2009$, concedo a medida liminar para determinar ao impetrado que se

${ }^{25}$ Verbis: "Art. 44. O servidor perderá: I - a remuneração do dia em que faltar ao serviço, sem motivo justificado; II - a parcela de remuneração diária, proporcional aos atrasos, ausências justificadas, ressalvadas as concessões de que trata o art. 97, e saídas antecipadas, salvo na hipótese decompensação de horário, até o mês subseqüente ao da ocorrência, a ser estabelecida pela chefia imediata.Parágrafo único. As faltas justificadas decorrentes de caso fortuito ou de força maior poderão ser compensadas a critério da chefia imediata, sendo assim consideradas como efetivo exercício. Art. 45. Salvo por imposição legal, ou mandado, nenhum desconto incidirá sobre a remuneração ou provento" Pelo exposto, defiro a cautela requerida para determinar que a ré se abstenha de todo e qualquer ato que venha a representar prejuízo administrativo, funcional e financeiro aos servidores em greve até a decisão final do dissídio coletivo". BRASIL. Superior Tribunal de Justiça. Medida Cautelar 16774/DF: Rel. Min. Hamilton Carvalhido. Publicado no DJE de 25/06/2010. Disponível em http://www.stj.jus.br/webstj/Processo/Justica/ sp?201000656463. Acesso em 14 nov. 2011. 
abstenha de proceder a descontos nos vencimentos dos servidores substituídos pelo Sindicato relativos aos dias parados em decorrência de movimento grevista, bem como que proceda à devolução dos valores em folha suplementar, caso os descontos já tenham sido efetivados. ${ }^{26}$

Quanto aos dissídios de greve de acordo com o Mandado de Injunção 712 foi estendido também aos servidores públicos, o direito a livre negociação, podendo o pagamento dos dias parados e a recuperação dos serviços serem negociados após o término da parede. Mas essa negociação, diferentemente da iniciativa privada é limitada, já que as partes não podem mudar a estrutura da Administração Pública limitando-se tão somente a negociar salários e direitos imediatamente a eles conexos, sempre se tendo em mente que se a greve for considerada ilegal ou abusiva, esta será incompatível com o recebimento de salários do período, já que o ilícito não pode gerar direitos. ${ }^{27}$

Para deflagrar uma greve, os servidores públicos deverão esgotar toda e qualquer hipótese de negociação com a Administração Pública, inclusive pela via arbitral. Isto quer dizer que o Supremo Tribunal Federal reconheceu os institutos da negociação coletiva e da via arbitral para compor e dar fim a controvérsias no serviço público, já que a Constituição Federal mandava aplicar aos servidores públicos alguns direitos aplicados aos trabalhadores em geral elencados no artigo $7^{\circ}$, mas excluía o inciso 26 , que era o que justamente falava do reconhecimento das convenções e acordos coletivos de trabalho.

Também aos servidores públicos foi estendida a imposição prevista no artigo $4^{\circ}$ da Lei n. 7.783/89 de que a entidade sindical representativa deverá convocar assembleia geral que definirá as reivindicações da categoria e deliberará sobre a paralisação do serviço. Deverá o estatuto da entidade sindical prever as formalidades de convocação e o quórum mínimo para deliberação, tanto da deflagração como do encerramento da greve.
Verifica-se que a jurisprudência já vem acompanhando este entendimento, como no caso da última greve dos servidores do Instituto Nacional do Seguro Social, onde o Superior Tribunal de Justiça manifestou-se da seguinte forma:

\begin{abstract}
no que tange ao cumprimento das formalidades necessárias à comunicação da greve (artigo 11 da legislação de regência), quanto aos critérios a serem adotados para a continuação dos serviços, observo que, neste ponto, não foram cumpridas as imposições legais, por parte da agravante. É que a falta de comprovação de tentativa válida para negociação prévia terminou por impedir a formação de consenso em torno dos critérios a serem estabelecidos para a continuação dos serviços a cargo da entidade autárquica. ${ }^{28}$
\end{abstract}

Em suma, de acordo com o disposto no acórdão do Mandado de Injunção 712, será considerada abusiva a greve no serviço público que violar os artigos da Lei n. 7.783/89, recepcionados no respectivo acórdão, mais especificamente os artigos $1^{\circ}$ a $9^{\circ}, 14,15$ e 17 , e principalmente, será abusiva a greve que não respeitar a continuidade da prestação dos serviços.

Outra grande alteração foi quanto aos serviços públicos essenciais, já que aos trabalhadores da iniciativa privada a Lei n. 7.783/89, no seu artigo 10, definiu o rol de serviços e atividades que se constituem essenciais, mas em relação aos servidores públicos o Mandado de Injunção 712 considerou todo o serviço público como essencial sem apresentar um rol específico.

O Estado tem responsabilidades e deveres com a população que não pode ficar à mercê de seus agentes. $\mathrm{O}$ Estado há de ser o primeiro, não o último, a observar as normas e zelar pela credibilidade da palavra dos que o representam ${ }^{29}$. O prejuízo causado pela atividade estatal ao particular sempre deve ser evitado, mas, se ocorrer, deve prontamente ser ressarcido em seus prejuízos, os quais acabou por suportar indebitamente. A responsabilidade estatal é a garantia da política como realização coletiva de
${ }^{26}$ BRASIL. Tribunal Regional Federal da 4a Região. Mandado de Segurança 0018196-20.2010.404.0000: Rel. Des. Federal Silvia Maria Gonçalves Goraieb. Publicado no Diário Eletrônico NE 119/10 em 28/06/2010. Disponível em: http://www.trf4. jus.br/trf4/processos/acompanhamento/?txtPalavraGerada-2 0.2010.404.0000. Disponível em 10 nov. 2011.

${ }^{27}$ SILVA, Antônio Álvares da. Greve no Serviço Público Depois da Decisão do STF. São Paulo: LTR. 2008, p. 153.

\footnotetext{
${ }^{28}$ BRASIL. Superior Tribunal de Justiça. Agravo Regimental na Medida Cautelar 15656/DF : Rel. Min. Og Fernandes, Publicado no DJE de 01/07/2009. Disponível em http://www.stj. jus.br/portal/pesquisas/jurisprudencia.asp\#ctx1. Acesso em 14 nov. 2011.

${ }^{29}$ FREITAS, Juarez. O controle dos atos administrativos e os princípios fundamentais. 3. ed São Paulo: Malheiros, 2004, p. 37.
} 
princípios éticos segundo os quais se tem o respeito dos direitos de todos. ${ }^{30}$

Assim, como o Estado tem responsabilidades ante a sociedade, o servidor público, enquanto agente representante do Estado, também as tem, já que o descumprimento de deveres e a não observância de proibições trazem consequências aos servidores públicos ${ }^{31}$.

Se o servidor não observar os ditames internos da Administração, sua responsabilidade será apenas administrativa e apurada no âmbito da própria Administração. Porém, se da sua conduta inadequada advirem danos à Administração, ao Erário Público ou a terceiros, será responsabilizado civilmente e, no caso de cometer algum crime, será responsabilizado criminalmente, sempre tendo em mente que as sanções civis, penais e administrativas podem cumular-se e são independentes entre si como diz o artigo 125 da Lei 8112/90.

Se o agente, por ação ou omissão, dolosa ou culposa, causou dano a Administração, deverá repará-lo, sendo responsabilizado civilmente. A apuração da responsabilidade civil poderá ter início e término no âmbito administrativo ou ter início nesse âmbito e ser objeto, depois, de ação perante o Judiciário. Se a conduta inadequada do agente afeta, de modo imediato, a sociedade e vem caracterizada pelo ordenamento como crime funcional, o servidor será responsabilizado criminalmente, podendo sofrer sanções penais. A responsabilidade criminal do servidor é apurada mediante processo penal, respectivos juízos. ${ }^{32}$

O servidor público estatutário não é um trabalhador comum, ainda que este também possa ser responsabilizado civil e criminalmente em razão de sua conduta,

${ }^{30}$ ROCHA, Cármen Lúcia Antunes. Princípios Constitucionais dos Servidores Públicos. São Paulo: Saraiva, 1999, p.368. Nesse sentido, Freitas consagrou o chamado direito fundamental à boa administração pública, advertindo que as escolhas administrativas serão legítimas se - e somente se - forem sistematicamente eficazes, motivadas, proporcionais, transparentes, imparciais, respeitadoras da participação social, da moralidade e da plena responsabilidade, conforme FREITAS, Juarez. Discricionariedade administrativa e o direito fundamental à boa administração pública. São Paulo: Malheiros, 2007, p. 23-24.

${ }^{31}$ COIMBRA, Rodrigo; ÁVILA, Paulo Ricardo Jubbet de. Tendências do exercício do direito de greve no serviço público após o julgamento do Mandado de Injunção 712 pelo Supremo Tribunal Federal. Justiça do Trabalho, Porto Alegre, ano 27, n. 322, p. 76, out. 2010.

${ }^{32}$ MEDAUAR, Odete. Direito Administrativo Moderno. 10. ed. São Paulo: Revista dos Tribunais, 2006, p. 298. esta responsabilização não tem a mesma abrangência e repercussão que a responsabilidade do servidor público ${ }^{33}$, sendo excluído da CLT e tutelado por estatuto, por escolha política- legislativa (art. 7º, alíneas “c" e "d" da CLT), pois efetivamente possui os elementos caracterizadores da relação de emprego.

Ao decidir pela greve, os servidores públicos ainda que abrangidos pelo direito da estabilidade funcional, devem considerar sempre as repercussões de sua decisão, pois tem obrigação de atender a interesses sociais e os direitos dos administrados que são impossíveis de serem protelados ou sujeitos à transferência no tempo e, mais do que quaisquer outras categorias de trabalhadores, estão sob o olhar atento da população em geral e submetidos à opinião pública. ${ }^{34}$

$\mathrm{Na}$ questão dos serviços públicos essenciais, o acórdão pretendeu diferenciar a greve no serviço público com a greve na iniciativa privada, dizendo que neste, a greve coloca em risco apenas os interesses egoísticos dos empresários voltados aos resultados financeiros, o que não ocorreria no serviço público quando os interesses dos servidores não correspondem antagonicamente a interesses individuais e sim a interesses sociais, já que a Administração Pública é a curadora dos interesses da sociedade. Mas considerar essencial a prestação do serviço público em todas as suas modalidades é um evidente exagero, que vai diminuir os efeitos da greve e além disso, ocasionar uma disputa judiciária paralela sobre quais serão os serviços efetivamente considerados essenciais nos diferentes ramos do serviço público. ${ }^{35}$

A regulamentação do exercício do direito de greve no serviço público é razoável e necessária, mas não foi correto qualificar genericamente todos os serviços prestados por servidores públicos como essenciais, na medida em que inúmeras atividades produtivas e de prestação de serviços desenvolvidas na iniciativa privada, como os

${ }^{33}$ COIMBRA, Rodrigo; ÁVILA, Paulo Ricardo Jubbet de. Tendências do exercício do direito de greve no serviço público após o julgamento do Mandado de Injunção 712 pelo Supremo Tribunal Federal. Justiça do Trabalho. Porto Alegre, p. 6981, 2010.

${ }^{34}$ ROCHA, Cármen Lúcia Antunes. Princípios Constitucionais dos Servidores Públicos. São Paulo: Saraiva. 1999, p.360.

${ }^{35}$ SILVA, Antonio Álvares da. Greve no Serviço Público Depois da Decisão do STF. São Paulo: LTR. 2008, p. 124. 
bancos, por exemplo, estariam a merecer o enquadramento de essencialidade. ${ }^{36}$

Assim definindo o serviço público como essencial no todo e estabelecendo como regra basilar à legalidade e não abusiva da greve, a instituição da manutenção dos serviços durante a parede sem prejuízos a população em geral, restringiu o Supremo Tribunal Federal o exercício ao direito de greve por parte dos servidores públicos. Já que em verdade o grande trunfo e o foco de uma greve, principalmente no serviço público, onde apesar de haver estabilidade, data-base, Fundo de Garantia por Tempo de Serviço - FGTS e principalmente dispositivos de negociação com a Administração Pública, é o prejuízo à população. Além do mais, é justamente a reclamação da população pela falta ou restabelecimento da prestação do serviço ante a Administração Pública o maior, senão o único elemento de pressão de que dispõem os servidores públicos.

Na verdade, ao estabelecer a continuidade dos serviços prestados sem estabelecer um padrão foi um retrocesso $^{37}$, pois se perdeu a oportunidade de informar quais seriam os critérios corretos, deixando neste quesito e em outros, lacunas que carecem de melhores explicações jurídicas e que com certeza serão tema para debate no judiciário por muito tempo.

\section{Da competência para julgamento dos dissí- dios de greve a partir da decisão do supremo tribunal federal no mandado de injunção $n$. 712}

Em relação a competência para o julgamento dos dissídios das demais questões relativas a greve no serviço público o artigo $8^{\circ}$ da Lei n. $7.783 / 89$, foi mantido na sua redação original:

\begin{abstract}
A Justiça do Trabalho, por iniciativa de qualquer das partes ou do Ministério Público do Trabalho, decidirá sobre a procedência, total ou parcial, ou improcedência das reivindicações, cumprindo ao Tribunal, publicar de imediato, o competente acórdão.
\end{abstract}

${ }^{36}$ FREDIANI, Yoni. Greve nos Serviços Essenciais à Luz da Constituição de 1988. São Paulo: LTR. 2001, p. 87.

${ }^{37}$ COIMBRA, Rodrigo; ÁVILA, Paulo Ricardo Jubbet de. Tendências do exercício do direito de greve no serviço público após o julgamento do Mandado de Injunção 712 pelo Supremo Tribunal Federal. Justiça do Trabalho, Porto Alegre, ano 27, n. 322, p. 77, out. 2010.
Em seu voto, o Ministro Eros Grau, no Mandado de Injunção 712, referiu-se à Justiça do Trabalho por pelo menos sete vezes, quando da interposição da Ação Direta de Inconstitucionalidade 3395, suscitada pela AJUFE Associação dos Juízes Federais e pela AMB - Associação dos Magistrados do Brasil, na qual foi suspensa a interpretação dada ao disposto no artigo 114 da Constituição Federal, na redação dada pela Emenda Constitucional 45/2004, no que tange a competência da Justiça do Trabalho a apreciação de causas que sejam instauradas entre o Poder Público e seus servidores a ele vinculados, por típica relação de ordem estatutária.

Todavia, a Ação Direta de Inconstitucionalidade 3395 era restrita a inconstitucionalidade parcial do art. 114, inciso I da Constituição Federal (relações individuais de trabalho). Em meio a todas essas significativas mudanças de entendimento jurisprudencial, o Supremo Tribunal Federal, ao julgar a Reclamação $6568^{38}$ sobre o dissídio coletivo de greve dos policiais civis do Estado de São Paulo, afastou a competência da Justiça do Trabalho devolvendo a reclamação para Justiça do Estado de São Paulo (retirando-a da Justiça do Trabalho de São Paulo, que em face da evolução da jurisprudência do Supremo Tribunal Federal entendeu-se competente para julgar o dissídio coletivo de greve instaurado).

Este entendimento se baseou no disposto no acórdão do Mandado de Injunção 708 que disciplinou a questão da competência para julgamento dos dissídios advindos da greve de servidores públicos determinando que Superior Tribunal de Justiça é competente para julgamento de dissídios de greve de servidores públicos se a paralisação for de âmbito nacional, ou abranger mais de uma região da justiça federal, ou ainda, compreender mais de uma unidade da federação. Se o dissídio estiver restrito a uma única região da justiça federal, a competência será dos Tribunais Regionais Federais.

Quanto à jurisdição no contexto estadual ou municipal, se o dissídio estiver adstrito a uma unidade da federação, a competência será do respectivo Tribunal de Justiça e as greves de âmbito local ou municipal serão dirimidas pelo Tribunal de Justiça ou Tribunal Regional

${ }^{38}$ BRASIL. Supremo Tribunal Federal. Reclamação 6568: Rel. Min. Eros Grau, Publicado no DJ 181 de 25/09/2009. Disponível em http://www.stf.jus.br/portal/constituicao/artigo. asp\#ctx1. Acesso em 14 nov. 2011. 
Federal com jurisdição sobre o local da paralisação, conforme se trate de greve de servidores municipais, estaduais ou federais. ${ }^{39}$

Além da definição dos Tribunais competentes para o julgamento dos dissídios de greve no serviço público, o Supremo Tribunal Federal no Mandado de Injunção 708, também estabeleceu a aplicação analógica da Lei n. 7.701/1988, devendo o Superior Tribunal de Justiça, os Tribunais Regionais Federais e os Tribunais de Justiça dos Estados criarem turmas e seções especializadas para a conciliação e julgamento destes dissídios.

Todavia, entende-se que o pronunciamento do Supremo Tribunal Federal deve ser analisado criticamente: “'intransponível' mesmo é a realidade da presença expressiva do Estado-Empregador, lembrando Pinho Pedreira", na conclusão de Ricardo Carvalho Fraga e Luiz Alberto $\operatorname{Vargas}^{40}$. E tal crítica passa pela necessidade de uma interpretação tópico-sistemática da problemática ora levantada: ao interpretar-se a norma que confere competência para julgamento das demandas trabalhistas envolvendo servidores públicos estatutários, deve-se interpretar o sistema inteiro, pois apenas no exame de conjunto tende a

39 "Até a devida disciplina legislativa, devem-se definir as situações provisórias de competência constitucional para a apreciação desses dissídios no contexto nacional, regional, estadual e municipal. Assim, nas condições acima especificadas, se a paralisação for de âmbito nacional, ou abranger mais de uma região da justiça federal, ou ainda, compreender mais de uma unidade da federação, a competência para o dissídio de greve será do Superior Tribunal de Justiça (por aplicação analógica do art. 2o, I, "a", da Lei no 7.701/1988). Ainda no âmbito federal, se a controvérsia estiver adstrita a uma única região da justiça federal, a competência será dos Tribunais Regionais Federais (aplicação analógica do art. 60 da Lei no 7.701/1988). Para o caso da jurisdição no contexto estadual ou municipal, se a controvérsia estiver adstrita a uma unidade da federação, a competência será do respectivo Tribunal de Justiça (também por aplicação analógica do art. 6o da Lei no 7.701/1988). As greves de âmbito local ou municipal serão dirimidas pelo Tribunal de Justiça ou Tribunal Regional Federal com jurisdição sobre o local da paralisação, conforme se trate de greve de servidores municipais, estaduais ou federais." BRASIL. Supremo Tribunal Federal. Mandado de Injunção 708: Rel. Min. Gilmar Mendes, Publicado no DJ 206 de 31/10/2008. Disponível em http://www.stf.jus.br/portal/processo/ProcessoAndamento. asp? numero=708. Acesso em 20 nov. 2011.

${ }^{40}$ Nesse sentido, FRAGA, Carvalho Ricardo; VARGAS, Luiz Alberto. O Direito de Greve dos Servidores Públicos após a Decisão do Supremo Tribunal Federal. Revista do Tribunal Regional do Trabalho da $4^{a}$ Região. Porto Alegre, v. 38, p. 48, 2010. ser melhor equacionado um caso problemático ${ }^{41}$. Ocorre que a relação jurídica que se estabelece com o ente público, ainda que haja um estatuto de classe é essencialmente trabalhista. Nesse sentido, analisando o sistema jurisdicional brasileiro inteiro, constatar-se-á a necessidade de mudança da competência para julgamento das demandas trabalhistas envolvendo servidores públicos estatutários, conforme os argumentos que se passa a expor.

Durante muito tempo, foi discutida, na jurisprudência, a natureza da relação existente entre servidor público e Estado. Após anos de discussão, a jurisprudência pacificou-se no sentido de que a relação teria natureza institucionalista (natureza jurídico-administrativa). A prevalência da teoria institucionalista, na qual a relação entre servidor e Estado é estabelecida de forma unilateral, mostrava, a princípio, a conveniência da manutenção do regime estatutário, pelo qual o Estado mantém um controle e uma possibilidade de exercício de poder sobre o servidor muito maior que no regime trabalhista ${ }^{42}$.

A realidade, entretanto, começou a desafiar a teoria porque, a partir de um determinado momento, a Administração Pública no Brasil passou a contratar massivamente pelo regime da CLT. Também no âmbito externo, a demanda pela atuação do Estado aproximou as relações de trabalho na função pública daquelas relações de trabalho existentes no setor privado ${ }^{43}$.

Na realidade, a diferenciação entre a atividade do servidor público e a do trabalhador comum acontece por escolha política-legislativa. Ontologicamente, ambas as atividades são exatamente iguais, ou seja, ocorre a prestação de trabalho subordinado, pessoal, não eventual e remunerado. Se um trabalhador do âmbito privado, ou um trabalhador ligado à Administração Pública não comparecerem ao trabalho, consequentemente não receberão a contraprestação, demonstrando tal fato duas assertivas: a) quem remunera o trabalhador é a sua força de trabalho e não o seu patrão, eis que o salário somente existirá se houver a prestação do serviço; b) em ambos os casos, tanto no âmbito privado, quanto na Administração Pública,

\footnotetext{
${ }^{41} \mathrm{Na}$ consagrada expressão de Juarez Freitas: "interpretar uma norma é interpretar o sistema inteiro", conforme FREITAS, Juarez. A interpretação sistemática do direito. 5 ed. São Paulo: Malheiros, 2010, p. 73.

${ }^{42}$ ARAÚJO, Francisco Rossal de. A boa-fé no contrato de emprego. São Paulo: LTr, 1996, p. 122-123.

${ }^{43}$ Ibidem, p. 122-123.
} 
o objeto da prestação é o mesmo para ambas as partes, ou seja, o trabalhador deve prestar serviço, e o patrão deve remunerá-lo. Mais uma vez, a condução do raciocínio leva à conclusão de que a diferenciação ocorre no âmbito jurídico, em função dos interesses do Estado ${ }^{44}$.

Toda a fundamentação de que a relação entre servidor público e Estado é unilateral e que este último é quem determina todos os elementos de execução, funda-se no argumento de que o servidor é um agente público, e sua atividade visa ao atendimento do bem-comum. Essa última acepção é correta, mas deve ser interpretada cuidadosamente. O servidor público, antes de assumir essa condição, é um cidadão, ao qual a lei assegura determinados direitos que nem mesmo o Estado pode molestar, principalmente se quisermos admitir a idéia do Estado de Direito. A noção de unilateralidade da relação entre o servidor público e o Estado tem conotação fascista, onde o indivíduo é tratado apenas como integrante de um grupo, e sua vontade deve ser considerada apenas como elemento componente da vontade maior do Estado. A incidência do princípio democrático, acolhido na Constituição Federal, colide frontalmente com tal posição $0^{45}$.

Afinal, se os servidores públicos estatutários brasileiros possuem todos os elementos caracterizadores da relação de emprego tradicionalmente previstos no Direito do Trabalho (art. $2^{\circ}$ e $3^{\circ}$ da CLT $)^{46}$ e se podem sindicalizar-se, fazer greve e negociar com o empregador, possuem vínculo de emprego com o Estado-Empregador a relação advinda daí é de natureza estritamente trabalhista, não administrativa.

Também entendendo ser equivocada a posição do Supremo Tribunal Federal, Reginaldo Melhado ${ }^{47}$ salienta que "com a redação da EC 45/04 esse modelo dicotômico foi afastado".

${ }^{44}$ ARAÚJO, Francisco Rossal de. A boa-fé no contrato de emprego. São Paulo: LTr, 1996, p. 123.

${ }^{45}$ ARAÚJO, Francisco Rossal de. A boa-fé no contrato de emprego. São Paulo: LTr, 1996, p. 126.

${ }^{46}$ Para um estudo detalhado dos elementos da relação tradicional de trabalho - a relação de emprego, ver COIMBRA, Rodrigo. Relações terceirizadas de trabalho. Curitiba: Juruá, 2007, p. 30-74.

${ }^{47}$ MELHADO, Reginaldo. Competência da Justiça do Trabalho. Curso de processo do trabalho. Luciano Athayde Chaves (Org.). São Paulo: Ltr, 2009, p. 199-200.
Mauro Schiavi ${ }^{48}$ chega a dizer que "mesmo antes da EC 45/04, nunca conseguimos entender porque a Justiça do Trabalho não tinha competência para apreciar as demandas que envolvam servidores estatutários", [...] "trata-se de uma autentica relação de emprego com todos os requisitos dos arts. $2^{\circ}$ e $3^{\circ}$ ambos da CLT [...]". Além disso, praticamente os direitos dos servidores estatutários são os mesmo direitos trabalhistas (vide art. 39, par. $3^{\circ}$, $\mathrm{CF}$ ). Praticamente, o servidor público só não tem direito ao FGTS, mas em troca tem a estabilidade prevista no art. 41 da CF".

Nesse contexto, entende-se que o legislador constituinte derivado (EC 45/2004, que alterou o caput do art. 114 da CF) já teve a intenção (mens legis) de determinar competência a Justiça do trabalho para julgar também as ações trabalhistas envolvendo servidores públicos estatutários, justamente porque este é órgão do Poder Judiciário Brasileiro mais apto para isso. Lembre-se que a EC 45/04 foi denominada de reforma do poder judiciário, justamente porque queira "reformar", melhorar a organização, a competência e ultimar a eficiência da prestação jurisdicional por quem é mais afeito a matéria.

O entendimento do Supremo Tribunal Federal ao julgar a ADI 3395, negando competência a Justiça do Trabalho (inclusive no mérito da ação), foi um "julgamento de conveniência, não de justiça”, conforme Álvares da Silva ${ }^{49}$.

Nesse sentido, após um estudo aprofundado e bastante fundamentado sobre o tema, Álvares da Silva ${ }^{50}$ conclui:

[...] Houve de fato a intenção do legislador em unificar em uma única jurisdição o trabalho humano. $[$...]

[...] Porém, o que se viu na prática foi a descaracterização do espírito da EC 45/04. A expressão "relação de trabalho", claramente expressa e doutrinariamente estabelecida, foi sofrendo deformações sucessivas na jurisprudência do STJ e STF, muitas vezes por falta de conhecimento especializado, não obstante a importância social de sua existência para o progresso e a crescimento do País. [...]

\footnotetext{
${ }^{48}$ SCHIAVI, Mauro. Manual de Direito Processual do Trabalho. 2 ed. São Paulo: Ltr, 2009, p. 177-178.

${ }^{49}$ SILVA, Antônio Álvares da. Competência da Justiça do trabalho para o julgamento de conflitos coletivos de trabalho de servidores públicos. Disponível em http://www.revistas.unifacs. br/index.php/redu/article/view/442. Acesso em 30 set. 2011.

${ }^{50}$ Ibidem.
} 
[...] Enquanto outras greves no serviço público se prolongam por meses, sem solução e causando sério prejuízo ao povo e ao erário público e aos próprios grevistas, esta dos servidores policiais civis teve pronto tratamento jurídico pelo TRT paulista mostrando que, no futuro decisões semelhantes serão tomadas em todo Brasil. $[\ldots]$

Ademais, a greve sabidamente se trata de direito coletivo (art. 114, parágrafo $3^{\circ}$, da CF) e não de direto individual do trabalho (art. 114, I, da CF), e, portanto, nada tem a ver com a ADI 3395, que se referia especificamente a uma parte do inciso I, do art. 114 da CF.

Nesse contexto, não há nenhum impedimento legal ou mesmo jurisprudencial (não se admite "inconstitucionalidade por analogia", nas palavras de Álvares da Silva $^{51}$ ), para que os conflitos coletivos de trabalho de servidores públicos celetistas e estatuários sejam ajuizados e julgados nos Tribunais do Trabalho (TRTs ou TST), conforme a abrangência territorial do conflito ${ }^{52}$.

Em sentido contrário e partilhando do atual entendimento do Supremo Tribunal Federal, Carlos Henrique Bezerra Leite sustenta que a decisão da ADI 3395 produz eficácia erga omnes, alcançando "as ações sobre greves oriundas da relação estatutária de servidores públicos investidos de cargos públicos, de provimento efetivo ou em comissão, bem como da relação jurídico administrativa dos servidores temporários, continuam na esfera de competência da Justiça Comum, federal ou estadual, conforme o caso.

\section{Considerações Finais}

Procurou-se, no presente ensaio, estudar um tema nada pacífico trazendo os fundamentos de cada posicionamento confrontante, de forma dialética. A dificuldade central do tema - além da importância que possui a ques-

\footnotetext{
${ }^{51}$ SILVA, Antônio Álvares da. Competência da Justiça do trabalho para o julgamento de conflitos coletivos de trabalho de servidores públicos. Disponível em http://www.revistas.unifacs. br/index.php/redu/article/view/442. Acesso em 30 set. 2011.

${ }^{52}$ A competência para apreciar dissídios coletivos é dos Tribunais do Trabalho: a) Tribunais Regionais do Trabalho, quando o conflito estiver relacionado à base territorial de um TRT (art. 678, I, a c/c art. $6^{\circ}$ da Lei n. 7.701/88); b) Tribunal Superior do Trabalho, quando o conflito envolver à base territorial de mais de um TRT (art. 702, I, b c/c art. $2^{\circ}$, I, a da Lei n. $7.701 / 88)$.
}

tão política, tendo em vista que competência sabidamente reflete-se em poder - é que histórica e culturalmente os servidores públicos foram sempre tratados como empregados “privilegiados” com relação jurídica de caráter jurídico-administrativo (estatutário) e não jurídico-trabalhista (CLT), como se não fossem trabalhadores, mas um ente abstrato pertencente a uma abstrata administração, que até historicamente não tem dado a devida atenção a concretização dessa importante política pública, que está ligada as escolhas políticas da nossa democracia ${ }^{53}$.

Porém, os tempos mudaram ${ }^{54}$ e esses "servidores" (empregados) cada vez mais se assemelham na realização os "atos materiais de execução do trabalho", como definiu Mario De La Cueva ${ }^{55}$, aos empregados da iniciativa privada, possuindo os elementos caracterizadores da relação de emprego (pessoalidade, subordinação, não eventualidade e onerosidade), sem a menor dúvida, vide as metas e a pressão de produção de trabalho que sofrem os servidores do poder judiciário, por exemplo, o que muito se assemelha ao que ocorre nos empregos privados.

Várias são as razões que podem ser apontadas para o crescimento dos conflitos dentro da Administração Pública, não só no Brasil. A racionalização e a modernização das relações entre os indivíduos não permitem a manutenção de certos estereótipos como a infalibilidade do Estado, ou a tradição burocrática de servir sem recla$\operatorname{mar}^{56}$. Com o decorrer do tempo, são introduzidos, no setor público, os métodos de pressão inerentes aos trabalhadores do setor privado, já que os trabalhadores do setor público, aos poucos, vão perdendo as vantagens que possuíam em relação àqueles ${ }^{57}$.

${ }^{53}$ A liberdade democrática pode certamente ser usada pra promover a justiça social e favorecer uma política melhor e mais justa. O processo, entretanto, não é automático e exige um ativismo por parte dos cidadãos politicamente engajados, conforme a lição de SEN, Amartya. A ideia de Justiça. São Paulo: Companhia das Letras, 2011, p. 386.

${ }^{54}$ FRIEDMAN, Thomas L. O mundo é plano: o mundo globalizado no século XXI. 3.ed. Rio de Janeiro: Objetiva, 2009, p. 21. DE MASI, Domenico. O futuro do trabalho: fadiga e ócio na sociedade pós industrial. 5.ed. Brasília: Unb, p. 2222272000

${ }_{55}^{5}$ DE LA CUEVA, Mario. El nuevo derecho mexicano del trabajo. 19. ed. México: Porruá, 2003. v.1, p. 187-195.

${ }^{56}$ CÓRDOVA, Efrén. Tendencias y Determinantes de las Huelgas en la Administración Pública. Revista Internacional del Trabajo. v. 104, n. 2, , p. 160, 1985.

${ }^{57}$ Ibidem, p. 160-161. 
As rígidas normas aplicáveis aos servidores públicos geram reações lideradas pelas organizações desses trabalhadores, que se vão dando conta da força de pressão que aquelas poderiam exercer. As greves realizadas obedeciam aos mesmos fatores determinantes das greves do setor privado, ou seja, nasciam do direito de organizarem-se em sindicatos, na ação direta e na negociação coletiva. O certo é que os sistemas tradicionais não responderam à demanda dos conflitos, o que motivou a criação de novos sistemas jurídicos ou mesmo de fato, para a resolução dos conflitos ${ }^{58}$.

Os juízes do trabalho não teriam condições de julgar relações trabalhistas regidas por um estatuto e não pela CLT? Primeiramente, dizia-se que a Justiça do trabalho não poderia julgar dano moral, por que a matéria era civil e assim sucessivamente. Atualmente a Justiça do Trabalho julga também matéria civil (dano moral e acidentes do trabalho, por exemplo), penal (habeas corpus, por exemplo), constitucional (habeas data, por exemplo), administrativa (questões administrativas e disciplinares de servidores dessa justiça e de seus juízes).

Pelo contrário, a Jurisdição Trabalhista está mais bem aparelhada e seus juízes possuem formação direcionada para julgar ações que envolvam trabalho subordinado, o que, muitas vezes, não é rotina das Justiças Estaduais e Federal ${ }^{59}$.

A concepção de Justiça de Amartya $\operatorname{Sen}^{60}$ subsidia a mudança de competência defendida no presente artigo: idéia de justiça comparativa focada em realizações, mas sem ignorar a importância das instituições, exatamente porque isso fortaleceria o poder judiciário (em sentido lato), ao passar o julgamento de ações que envolvam trabalho subordinado de servidores regidos por estatutos, para a instituição especializada nisso no Brasil (Justiça do Trabalho), maximizando-se com isso as realizações da

${ }^{58}$ CÓRDOVA, Efrén. Tendencias y Determinantes de las Huelgas en la Administración Pública. Revista Internacional del Trabajo. v. 104, n. 2, , p. 160, 1985. p. 162-163.

${ }^{59}$ Nesse sentido também, por exemplo: SCHIAVI, Mauro. $M a-$ nual de Direito Processual do Trabalho. 2.ed. São Paulo: Ltr, p. 177-178, 2009. prestação jurisdicional para os jurisdicionados (no caso os muitos servidores públicos estatutários) ${ }^{61}$.

Esse posicionamento atual acerca do julgamento das eventuais reclamações trabalhistas de servidores públicos estatutários, notadamente as resultantes de conflitos coletivos de trabalho fora da competência da Justiça do Trabalho está focado mais nas instituições (que detém a competência atual) que no jurisdicionado. Em última análise, a manutenção desse entendimento está na contra mão da reconhecida necessidade de termos uma prestação jurisdicional adequada, efetiva e que atenda a ordem jurídica, pois: a) a Justiça do Trabalho, enquanto braço do poder judiciário especializado em julgar conflitos individuais e coletivos resultantes das relações de trabalho em sentido lato, está mais bem aparelhada para tanto e seus juízes possuem formação direcionada para julgar ações que envolvam trabalho subordinado, o que, muitas vezes, não é rotina das Justiças Estaduais e Federal; b) a Justiça do Trabalho, dentro do contexto do sistema jurídico brasileiro, é um dos órgãos jurisdicionais que cumpre a sua prestação jurisdicional com maior celeridade e efetividade, estando mais próxima do cumprimento do preceito constitucional de razoável duração do processo ${ }^{62}$ (atendimento da ordem jurídica) que os demais órgãos jurisdicionais (Federais e Estaduais), no que concerne ao julgamento de ações que envolvam trabalho subordinado.

Ainda que se sustente no presente artigo que a competência da Justiça do Trabalho também para o julgamento de demandas trabalhistas individuais promovidas por servidores públicos estatutários, pelos argumentos acima expostos, é necessário ser ter presente a ADI 3395 julgou inconstitucional apenas parte do art. 114, inciso I, da CF que trata de trata de direitos trabalhistas individuais e a greve é um direito trabalhista coletivo (art. 114, parágrafo $3^{\circ}$, da CF), portanto não foi afetado por essa inconstitucionalidade parcial e específica. Isso significa que não há nenhum impedimento

${ }^{61}$ Nesse sentido, Juarez Freitas após chamar a atenção para a natureza pluridimensional da sustentabilidade e o entrelaçamento de suas dimensões, adverte para a importância da sustentabilidade do Estado: "O Estado Sustentável, no século em curso, tem de operar em modelo que dê conta da responsabilidade pelas presentes e futuras gerações, sem omissão e em tempo útil", conforme FREITAS, Juarez. Sustentabilidade: direito ao futuro. Belo Horizonte: Fórum, 2011, p. 53, 278 e 281-282.

${ }^{62} \mathrm{CF}$, art. 5, LXXVIII: "a todos, no âmbito judicial e administrativo, são assegurados a razoável duração do processo e os meios que garantam a celeridade de sua tramitação". (Incluído pela Emenda Constitucional no 45, de 2004). 
legal ou mesmo jurisprudencial, para que os conflitos coletivos de trabalho de servidores públicos celetistas e estatuários sejam ajuizados e julgados nos Tribunais do Trabalho (TRTs ou TST), conforme a abrangência territorial do conflito.

Dentro da concepção de segurança do próprio direito, aliada a noção tradicional de estabilidade das relações sociais, e na trilha atual de reaproximação entre o direito material e processual ${ }^{63}$, somada a necessidade de interseção entre segurança jurídica e efetividade, os conflitos coletivos de trabalho de servidores públicos celetistas e estatuários devem ser sejam ajuizados e julgados nos Tribunais do Trabalho, mediante o procedimento ${ }^{64}$ vigente na Justiça do Trabalho, rumo ao desiderato de concretização da Constituição e dos direitos fundamentais ${ }^{65}$, mediante o julgamento mais adequado, efetivo e que atenda a ordem jurídica ${ }^{66}$.

${ }^{63}$ TESHEINER, José Maria. Reflexões politicamente incorretas sobre direito e processo. Revista da Ajuris. Porto Alegre: Ajuris, n. 110, p. 192, Jun. 2008. MARINONI, Luiz Guilherme. Tutela inibitória: individual e coletiva. 2.ed. São Paulo: Editora Revista dos Tribunais, 2000, p. 395-396; CAPPELLETTI, Mauro. Juízes legisladores? Porto Alegre: Fabris, 1993, p. 13.

${ }^{64}$ FAZZALARI, Elio. Procedimento e processo: (teoria generale). Enciclopedia del diritto. Milano: Giuffrè, v. 35, 1975.

${ }^{65}$ CANOTILHO, José Joaquim Gomes. Direito Constitucional. 5.ed. Coimbra: Almedina, 1991, p. 384; SARLET, Ingo Wolfgang. A eficácia dos direitos fundamentais. 5.ed. Porto Alegre: Livraria do Advogado, 2005, p. 254-258.

${ }^{66}$ Porto e Ustarroz salientam que "É a Constituição que harmoniza as expectativas do jurisdicionado e a atuação do magistrado em cada relação processual" (PORTO, Sérgio Gilberto; USTÁRROZ, Daniel. Lições de direitos fundamentais no processo civil: o conteúdo processual da Constituição Federal. Porto Alegre: Livraria do Advogado Editora, 2009, p. 37); Nesse sentido, Wieacker diz que: “A justiça apenas é compreensível como respeito de um dever ser supra-pessoal pelo indivíduo em cuja experiência pessoal ela aparece como uma visão sobre o valor do direito. Ela não é um dever geral, que deva ser desligado da pessoa tocada por tal experiência, mas um comando específico e espontâneo dirigido a uma certa pessoa numa certa e determinada decisão" (WIEACKER, Frantz. História do direito privado moderno. 2.ed. Lisboa: Fundação Calouste Gulbenkian, 1993, p. 706); OLIVEIRA, Carlos Alberto Alvaro de. O processo civil na perspectiva dos direitos fundamentais. Revista de Processo. São Paulo, n. 113. p. 20, fev. 2004. MITIDIERO, Daniel. Processo civil e estado constitucional. Porto Alegre: Livraria do Advogado Editora, 2007, p. 62-63; Botelho fala que o "processo qualificado" (representado por três características centrais: tempestividade, justiça e adequação), enquanto "modo de pensar o direito processual civil pelas lentes do Estado Constitucional", consegue manter em seu conteúdo a segurança jurídica e a efetividade, "ao unificar as qualidades que devem formar o processo devido à sociedade" BOTELHO, Guilherme. Direito ao processo qualificado: o processo civil na perspectiva do estado constitucional. Porto Alegre: Livraria do Advogado Editora, 2010, p. 15 e 16.

\section{Referências}

ARAÚJO, Francisco Rossal de. A boa-fé no contrato de emprego. São Paulo: LTr, 1996.

BOTELHO, Guilherme. Direito ao processo qualificado: o processo civil na perspectiva do estado constitucional. Porto Alegre: Livraria do Advogado, 2010.

BRITO FILHO, Jose Cláudio Monteiro de. Direito Sindical. São Paulo: LTR. 2000.

CANOTILHO, José Joaquim Gomes. Direito Constitucional. 5.ed. Coimbra: Almedina, 1991.

CAPPELLETTI, Mauro. Juizes legisladores? Porto Alegre: Fabris, 1993.

COIMBRA, Rodrigo. Direito do Trabalho. Novo Hamburgo: Feevale, 2006.

COIMBRA, Rodrigo; ÁVILA, Paulo Ricardo Jubbet de. Tendências do exercício do direito de greve no serviço público após o julgamento do Mandado de Injunção 712 pelo Supremo Tribunal Federal. Justiça do Trabalho, ano 27, n. 322, p. 69-81, out. 2010.

COIMBRA, Rodrigo. Relações terceirizadas de trabalho. Curitiba: Juruá, 2007.

COIMBRA, Rodrigo. ARAÚJO, Francisco Rossal de. Direito do Trabalho: evolução do modelo normativo e tendências atuais na Europa. Revista Ltr. São Paulo: Ltr, ano 73, t. II, n. 08, p. 953-62, ago. 2009.

CÓRDOVA, Efrén. Tendencias y Determinantes de las Huelgas en la Administración Pública. Revista Internacional del Trabajo, v. 104, n. 2, 1985.

CRETELLA JUNIOR, José. Curso de Direito Administrativo. 18 ed. Rio de Janeiro: Forense. 2006.

DI PIETRO, Maria Sylvia Zanella. Direito Administrativo. 21. Ed. São Paulo: Atlas, 2008.

DE LA CUEVA, Mario. El nuevo derecho mexicano del trabajo. V.1. 19.ed. México: Porruá, 2003.

DE MASI, Domenico. O futuro do trabalho: fadiga e ócio na sociedade pós industrial. 5.ed. Brasília: Unb, 2000.

FAZZALARI, Elio. Procedimento e processo: (teoria generale). Enciclopedia del diritto. Milano: Giuffrè, v. 35, 1975.

FINCATO, Denise Pires. A pesquisa jurídica sem mistérios: do projeto de pesquisa à banca. Porto Alegre: Notadez, 2008. 
FRAGA, Carvalho Ricardo; VARGAS, Luiz Alberto. O Direito de Greve dos Servidores Públicos após a Decisão do Supremo Tribunal Federal. Revista do Tribunal Regional do Trabalho da 4a Região. v. 38, 2010.

FREDIANI, Yoni. Greve nos Serviços Essenciais à Luz da Constituição de 1988. São Paulo: LTR. 2001.

FREITAS, Juarez. A interpretação sistemática do direito. 5.ed. São Paulo: Malheiros, 2010.

FREITAS, Juarez. Discricionariedade administrativa $e$ o direito fundamental à boa administração pública. São Paulo: Malheiros, 2007.

FREITAS, Juarez. $O$ controle dos atos administrativos $e$ os princípios fundamentais. 3. ed. São Paulo: Malheiros, 2004.

FREITAS, Juarez. Sustentabilidade: direito ao futuro. Belo Horizonte: Fórum, 2011.

FRIEDMAN, Thomas L. O mundo é plano: o mundo globalizado no século XXI. 3.ed. Rio de Janeiro: Objetiva, 2009.

MARINONI, Luiz Guilherme. Tutela inibitória: individual e coletiva. 2.ed. São Paulo: Editora Revista dos Tribunais, 2000.

MEDAUAR, Odete. Direito Administrativo Moderno. 10. ed. São Paulo: Revista dos Tribunais, 2006.

MEIRELLES, Hely Lopes. Direito administrativo brasileiro. 35. ed. São Paulo: Malheiros Editores, 2009.

MELHADO, Reginaldo. Competência da Justiça do Trabalho. Curso de processo do trabalho. Luciano Athayde Chaves (org.). São Paulo: Ltr, 2009.

MEZZAROBA, Orides; MONTEIRO, Cláudia Servilha. Manual de Metodologia da Pesquisa no Direito. 3.ed. São Paulo: Saraiva, 2006.

MITIDIERO, Daniel. Processo civil e estado constitucional. Porto Alegre: Livraria do Advogado Editora, 2007.

MORAES, Alexandre de. Direito Constitucional. 24. ed. São Paulo: Atlas, 2009.

OLIVEIRA, Carlos Alberto Alvaro de. Do formalismo no processo civil. 2.ed. São Paulo: Saraiva, 2003.

OLIVEIRA, Carlos Alberto Alvaro de. O processo civil na perspectiva dos direitos fundamentais. Revista de Processo. São Paulo, n. 113, p. 9-21, fev. 2004.
PORTO, Sérgio Gilberto; USTÁRROZ, Daniel. Lições de direitos fundamentais no processo civil: o conteúdo processual da Constituição Federal. Porto Alegre: Livraria do Advogado, 2009.

PISTORI, Gerson Lacerda. Direito de greve: origens históricas e sua repercussão no Brasil. Caderno de Doutrina e Jurisprudência da Ematra XV. v.1, n.2, p. 3743, mar./abr. 2005.

ROCHA, Cármen Lúcia Antunes. Princípios Constitucionais dos Servidores Públicos. São Paulo: Saraiva. 1999.

ROMITA, Arion Sayão. Direito do Trabalho: Temas em Aberto. São Paulo: LTR. 1998.

SARLET, Ingo Wolfgang. A eficácia dos direitos fundamentais. 5.ed. Porto Alegre: Livraria do Advogado, 2005.

SCHIAVI, Mauro. Manual de Direito Processual do Trabalho. 2.ed. São Paulo: Ltr, 2009.

SEN, Amartya. A ideia de Justiça. São Paulo: Companhia das Letras, 2011.

SILVA, Antônio Álvares da. Greve no Serviço Público Depois da Decisão do STF. São Paulo: LTR. 2008.

SILVA, Antônio Álvares da. Competência da Justiça do trabalho para o julgamento de conflitos coletivos de trabalho de servidores públicos. Disponível em http://www.revistas. unifacs.br/index.php/redu/article/view/442. Consulta em 30 set. 2011.

SILVA, Jose Afonso da. Curso de Direito Constitucional Positivo. 32. ed. São Paulo: Malheiros Editores, 2009.

BRASIL. Supremo Tribunal Federal. Mandado de Injunção $n^{\circ} 20$ : Rel. Min. Celso de Mello, Publicado no DJ de 22/11/1996. Disponível em http://www.stf.jus.br/ portal/constituicao/artigo.asp\#ctx1. Consulta em 05 nov. 2011.

BRASIL. Supremo Tribunal Federal. Mandado de Injunção 708: Rel. Min. Gilmar Mendes, Publicado no DJ 206 de 31/10/2008. Disponível em http://www.stf.jus.br/ portal/processo/ProcessoAndamento.asp? numero $=708$. Consulta em 20 nov. 2011.

BRASIL. Supremo Tribunal Federal. Mandado de Injunção no 712. Rel. Min. Eros Grau, Publicado no DJ de 25/10/2007. Disponível em http://www.stf.jus.br/portal/ constituicao/artigo.asp\#ctx1. Consulta em 05 nov. 2011. 
BRASIL. Superior Tribunal de Justiça. Agravo Regimental na Medida Cautelar 15656/DF: Rel. Min. Og Fernandes, Publicado no DJE de 01/07/2009. Disponível em http:// www.stj.jus.br/portal/pesquisas/jurisprudencia.asp\#ctx1. Consulta em 14 nov. 2011.

BRASIL. Superior Tribunal de Justiça. Medida Cautelar 16774/DF: Rel. Min. Hamilton Carvalhido. Publicado no DJE de 25/06/2010. Disponível em http://www.stj.jus.br/ webstj/Processo/Justica/sp?201000656463.Consulta em 14 nov. 2011.

BRASIL. Supremo Tribunal Federal. Reclamação 6568: Rel. Min. Eros Grau, Publicado no DJ 181 de 25/09/2009. Disponível em http://www.stf.jus.br/portal/constituicao/ artigo.asp\#ctx1. Consulta em 14 nov. 2011
TESHEINER, José Maria Rosa. Reflexões politicamente incorretas sobre direito e processo. Revista da Ajuris. Porto Alegre, n. 110, p. 187-194, jun. 2008.

BRASIL. Tribunal Regional Federal da $4^{\mathrm{a}}$ Região. Mandado de Segurança 0018196-20.2010.404.0000: Rel. Des. Federal Silvia Maria Gonçalves Goraieb. Diário Eletrônico NE 119/10 em 28/06/2010. Disponível em: http://www.trf4.jus.br/trf4/processos/acompanhamento /?txtPalavraGerada- 20.2010.404.0000. Consulta em 10 nov. 2011.

WIEACKER, Frantz. História do direito privado moderno. 2.ed. Lisboa: Fundação Calouste Gulbenkian, 1993. 


\section{Para publicar na revista Universitas/JUS, acesse $o$ endereço eletrônico www.publicacoesacademicas.uniceub.br.}

Observe as normas de publicação, para facilitar e agilizar o trabalho de edição. 